\title{
Analisis Manajemen Pemenuhan Pelanggan pada Industri Kecil Menengah Pembuatan Tas dan Bordir Menggunakan Pemodelan System Dynamics (Studi Kasus pada CV. Kurnia Jaya - Yogyakarta)
}

\author{
Nurdin Rahmanto \\ Jurusan Teknik Mesin dan Industri, Fakultas Teknik UGM \\ Jl. Grafika No.2, Yogyakarta 55281 \\ Budi Hartono \\ Jurusan Teknik Mesin dan Industri, Fakultas Teknik UGM \\ Jl. Grafika No.2, Yogyakarta 55281 \\ Alva Edy Tontowi \\ Jurusan Teknik Mesin dan Industri, Fakultas Teknik UGM \\ Jl. Grafika No.2, Yogyakarta 55281
}

\begin{abstract}
Small Medium Enterprise (SME) plays a strategic role in developing countries economy. Each of SMEs has unique strategy of order fulfillment management. This is influenced by factor dynamics influencing the system. The system characteristic becomes the inspiration to be studied furthermore continues especially using system dynamics modeling approach. System dynamics modeling approach used because this method used to know and learn the system behavior. This paper represents of order fulfillment management analysis with case study at CV. Kurnia Jaya - Yogyakarta. The developed model has 4 sub models: customer order sub model, order fulfillment sub model, raw material management sub model and labor sub model. Next step is calibrating the developed model with boundary adequacy test, extreme conditions test and behavior reproduction test. After passing all these steps, the developed model to be ran with policy design (different scenario of order such as: constant order, step order, impulse order and actual order). Finally 3 alternative recommendations proposed for increasing the production rate so the order backlog and delivery delay decrease.

Keywords: SME, order fulfillment management system, simulation, system dynamics, system behavior.

\section{Pendahuluan}

Dalam perjumpaan manusia dengan hidup dan kehidupan, semakin hari manusia semakin yakin bahwa gerak, dinamika dan perubahan-perubahan adalah bagian dari keduanya. Menyikapi hal itu, manusia dituntut untuk dapat melakukan adaptasi setiap menjalani kehidupan ini sebagaimana pepatah Romawi "Crescit in cundo" yang artinya
\end{abstract}


bertumbuh selagi berjalan. Dalam arti lebih luas, perubahan adalah esensi dan pertanda kehidupan (Mulyani, 2006).

Sektor industri kecil dan menengah (IKM) merupakan Unit Kecil Menengah (UKM) yang bergerak pada sektor industri. IKM berperan cukup strategis terutama dalam memberikan kontribusi pertumbuhan di sektor ekonomi bagi negara berkembang (Haroon dan Wahba, 2002). Menurut Samhadi (2006) sektor informal di Indonesia yang diwakili oleh Usaha Kecil Menengah dan Koperasi (UKMK) terbukti mampu menunjukkan ketangguhan dan mampu menjadi peredam (buffer) gejolak di pasar kerja perkotaan di saat krisis ekonomi melanda Indonesia pada tahun 1997. Pada pasca krisis sektor ini mampu menjadi katup pengaman di tengah ketidakmampuan pemerintah dan sektor formal menyediakan lapangan kerja.

Salah satu hal yang cukup menarik untuk dicermati adalah kemampuan para pengusaha-pengusaha yang bergerak pada sektor industri kecil dan menengah di tanah air untuk menganalisis potensi diri dan potensi perusahaan yang dimiliki. Menurut Schultz seperti yang disampaikan oleh Rohmah (2006) pengenalan diri yang memadai menuntut pemahaman tentang hubungan atau perbedaan antara gambaran tentang diri yang dimiliki seseorang (perusahaan) tentang dirinya menurut keadaan yang sesungguhnya, dan hubungan antara apa yang dipikirkan orang lain tentang dirinya. Dengan mengenali diri, individu maupun perusahaan akan mengetahui kebutuhan, cita-cita, kelebihan serta kekurangan diri. Terlebih jika hal ini dikaitkan dengan order fulfillment management (manajemen pemenuhan pesanan) dalam sebuah perusahaan. Manajemen pemenuhan pesanan merupakan satu faktor kritis dengan satu alasan : produk harus datang tepat waktu agar memberikan keuntungan dari kesempatan penjualan yang ada (Brownell, 2003) . Sehingga diharapkan perusahaan akan mampu memenuhi pesanan dengan berpijak pada semboyan "delivery it to the right place, at the right time for the right price" (Murphy, 2004).

Berkembangnya pendekatan pemodelan tampaknya merupakan salah satu alternatif yang dapat dipergunakan untuk mempelajari sekaligus memberikan solusi optimal terhadap permasalahan-permasalahan yang terjadi. Salah satu pendekatan pemodelan yang dikembangkan adalah pemodelan dinamis (system dynamics). Berbeda dengan pemodelan statis di mana perhitungan dilakukan satu waktu, di dalam pemodelan dinamis perhitungan dilakukan berulang kali sesuai dengan perubahan waktu. Sehingga memungkinkan untuk mempelajari dinamika sistem dan hubungan sebab akibat antara faktor dalam sistem tersebut.

System dynamic lahir dari sebuah simulasi sederhana mengenai pengontrolan sistem inventori dengan menggunakan pensil dan kertas note book (Forrester, 1989). Berawal dari yang simulasi sederhana ini akhirnya system dynamics banyak diaplikasikan untuk memecahkan permasalahan komplek seperti business process reengineering, system development, secientific understanding (Sterman, 2000). Tak heran jika saat ini banyak dijumpai literatur dan publikasi tentang dinamika sistem pada perusahaan besar. Hal ini bertolak belakang dengan jumlah literatur dan publikasi yang mengungkap dinamika sistem pada industri kecil dan menengah untuk dinamika rantai pasok (Sopha dan Hartono, 2006) terutama untuk sistem pemenuhan pesanan pelanggan. Padahal jika ditelaah kembali, system dynamics sebenarnya sangat 
customized (Sterman, 2000) yang dapat dipergunakan untuk pemodelan dinamika sistem pada industri kecil dan menengah di Indonesia.

\section{Metode Penelitian}

Penelitian ini dilaksanakan sesuai dengan langkah kerja sebagai berikut :

Pertama dirumuskan problem formulation berupa penentuan tujuan penelitian. Selanjutnya dilakukan observasi dan pengumpulan data.

Langkah paling penting dalam tahapan pemodelan adalah penentuan batasan permasalahan yang lebih dikenal dengan sebutan problem articulation (boundary selection). Hal-hal yang termasuk dalam kegiatan problem articulation meliputi : theme selection, key variables, time horizon dan dynamic problem definition (reference modes).

Langkah selanjutnya adalah formulasi hipotesis dinamik (formulation of dynamic hypothesis) yang meliputi : initial hypothesis generation, endogenous focus dan mapping. Sebenarnya pada tahapan ini lebih difokuskan pada mapping berupa pengembangan pemetaan causal structure berdasarkan hipotesis awal, variabelvariabel penting, reference modes serta data lain yang tersedia menggunakan tool seperti : model boundary diagrams, causal loop diagrams, stock and flow diagrams. Hal terpenting adalah sejak tahapan pengumpulan data hingga formulasi hipotesis dinamik adalah pendekatan participative dialogue antara fasilitator (modeler) dengan pihak klien.

Setelah itu dilakukan simulasi sistem dinamik menggunakan bantuan software sistem dinamik yaitu Powersim Studio 2005 Service Release 4 enterprise version. Model yang dikembangkan mengalami 3 tahapan kalibrasi : boundary adequacy test, extreme condition test dan behaviour reproduction test. Pada tahapan extreme condition test dilakukan 5 skenario berupa customer order bernilai nol, productivity bernilai nol, machines capacity bernilai nol, selama periode simulasi hanya terjadi 1 kali customer order sebesar 100 unit dan customer order sebesar 700 unit yang melebihi machines capacity. Sedangkan untuk behavior reproduction test dengan cara membandingkan antara output sistem nyata dengan output model. Pengujian ini menggunakan paired $t-$ test.

Setelah model dinyatakan lulus keseluruhan tahapan kalibrasi maka dilakukan tahapan policy design. Tahapan ini bertujuan mengetahui dan mempelajari perilaku sistem terhadap jenis skenario simulasi yang berbeda. Adapun jenis skenario simulasi yang dilakukan adalah : constant order, step order, impulse order dan actual order. Hasil simulasi setiap skenario diintepretasikan dan dianalisa. Hasil analisa ini akan dirumuskan alternatif rekomendasi perbaikan sistem yang selanjutnya dirumuskan kesimpulan apakah sesuai dengan tujuan penelitan semula. Adapun langkah-langkah kerja penelitian dapat dilihat pada Gambar 1. 


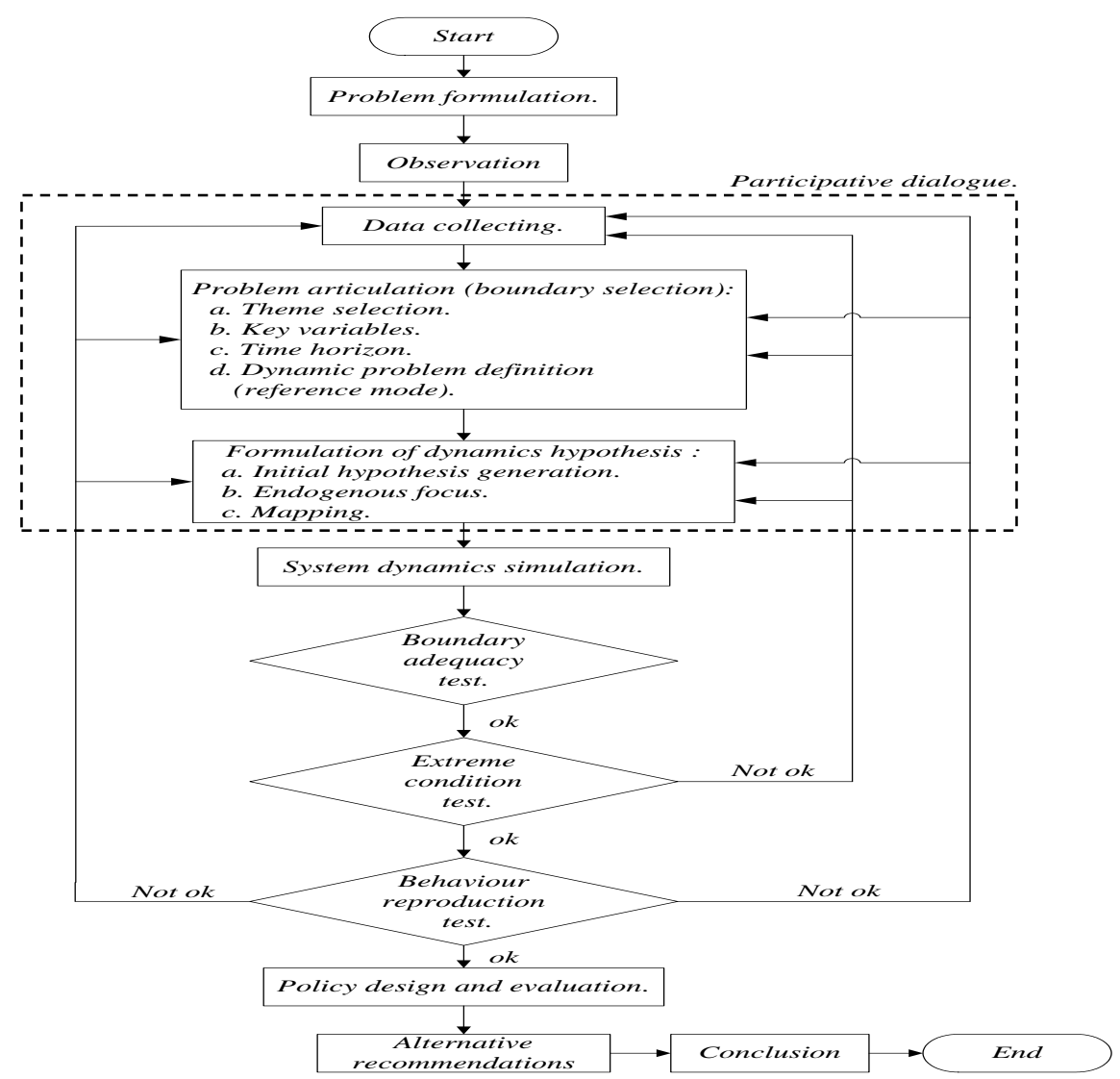

Gambar 1. Diagram Alir Penelitian

\section{Hasil Penelitian}

Hasil tahap pengumpulan data (data collecting) dan problem articulation disajikan dalam Tabel 1.

Tabel 1. Tahapan Problem Articulation

\begin{tabular}{|c|c|c|c|}
\hline No & Tahapan & Keterangan & \\
\hline 1. & Theme selection & $\begin{array}{l}\text { Mengetahui dinamika order fulfillment management } \\
\text { CV. Kurnia Jaya }\end{array}$ & \\
\hline 2. & Key variables & $\begin{array}{l}\text { Order backlog } \\
\text { Order completion rate (production rate) } \\
\text { Delivery delay } \\
\text { Raw material inventory } \\
\text { Labor }\end{array}$ & $\begin{array}{l}\text { [unit] } \\
\text { [unit/day] } \\
{[\text { day] }} \\
\text { [unit] } \\
\text { [people] }\end{array}$ \\
\hline 3. & Time horizon & $\begin{array}{l}7 \text { bulan (periode bulan } 1 \text { Februari sampai dengan } 1 \\
\text { September 2006). Hal ini berdasarkan kesepakatan } \\
\text { dengen klien dengan mempertimbangkan siklus causal } \\
\text { loop diagram yang akan dibangun. }\end{array}$ & \\
\hline 4. & $\begin{array}{l}\text { Dynamic } \\
\text { problem } \\
\text { definition } \\
\text { (reference } \\
\text { modes) }\end{array}$ & $\begin{array}{l}\text { Reference mode sistem belum ada sehingga hal ini akan } \\
\text { diamati melalui perilaku variabel-variabel penting dengan } \\
\text { menggunakan bantuan software powersim. }\end{array}$ & \\
\hline
\end{tabular}


Sedangkan pada tahapan formulation of dynamics hypothesis terutama pada sub tahapan mapping dilakukan pemetaan causal structure dengan Model Boundary Diagram (MBD) seperti pada Gambar 2, Causal Loop Diagrams (CLDs) seperti pada Gambar 3 dan Stock and Flow Diagram terdiri dari 4 sub model yaitu sub model customer order sub model order fulfillment, sub model raw material management dan sub model labor. Pada Gambar 4 disajikan satu model yang merupakan penggabungan dari keempat sub model tersebut.

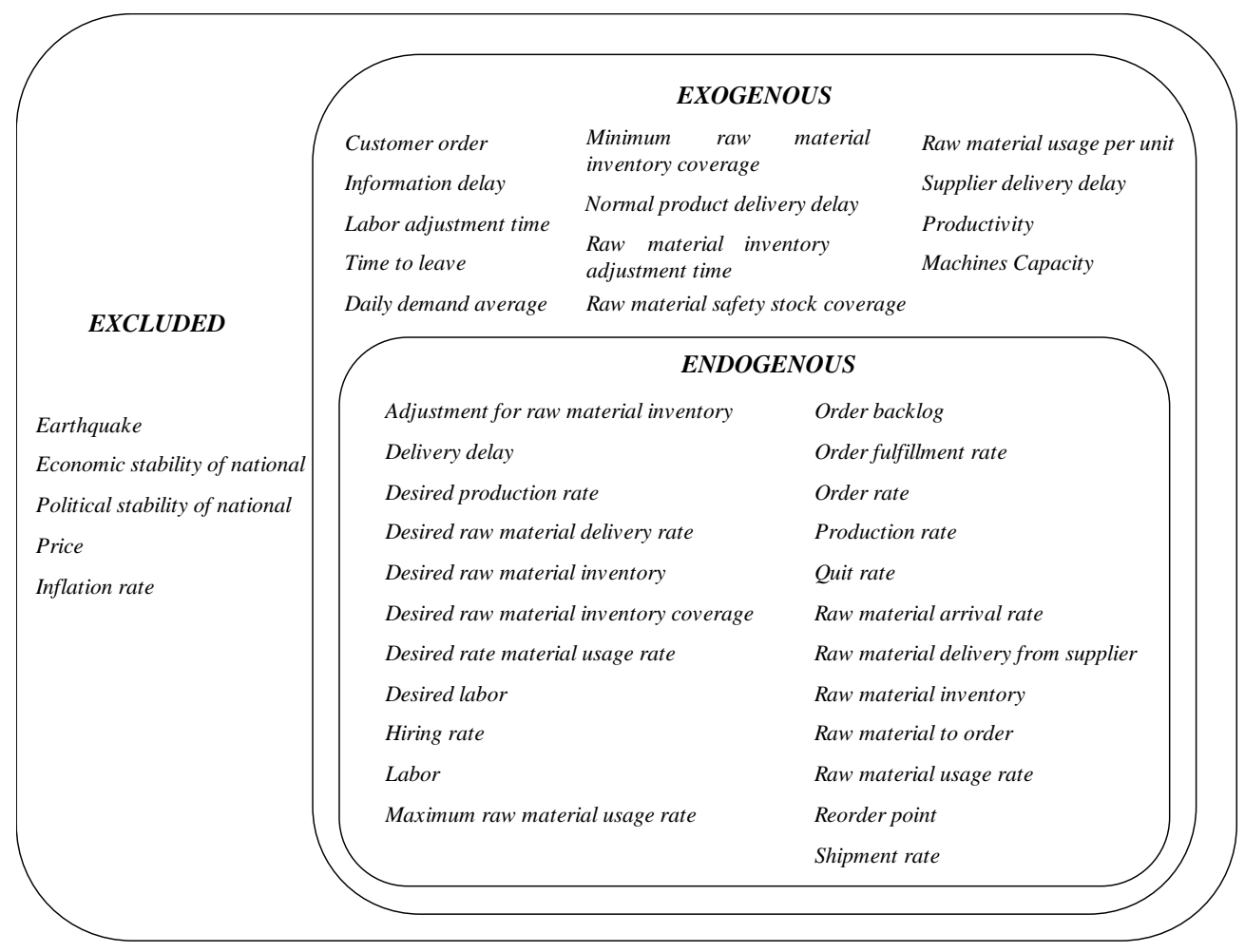

Gambar 2. Model Boundary Diagram (MBD)

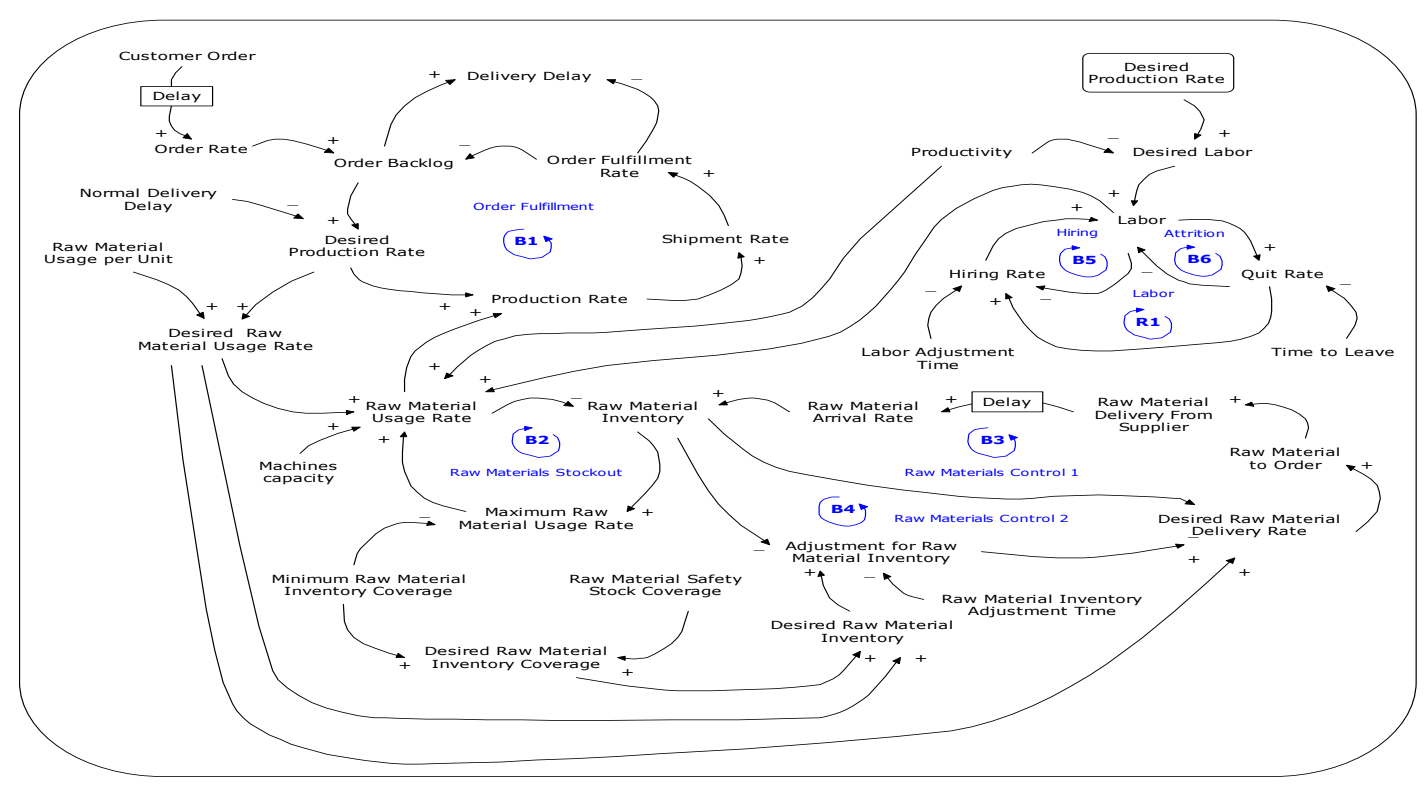

Gambar 3. Causal Loop Diagrams (CLDs) 


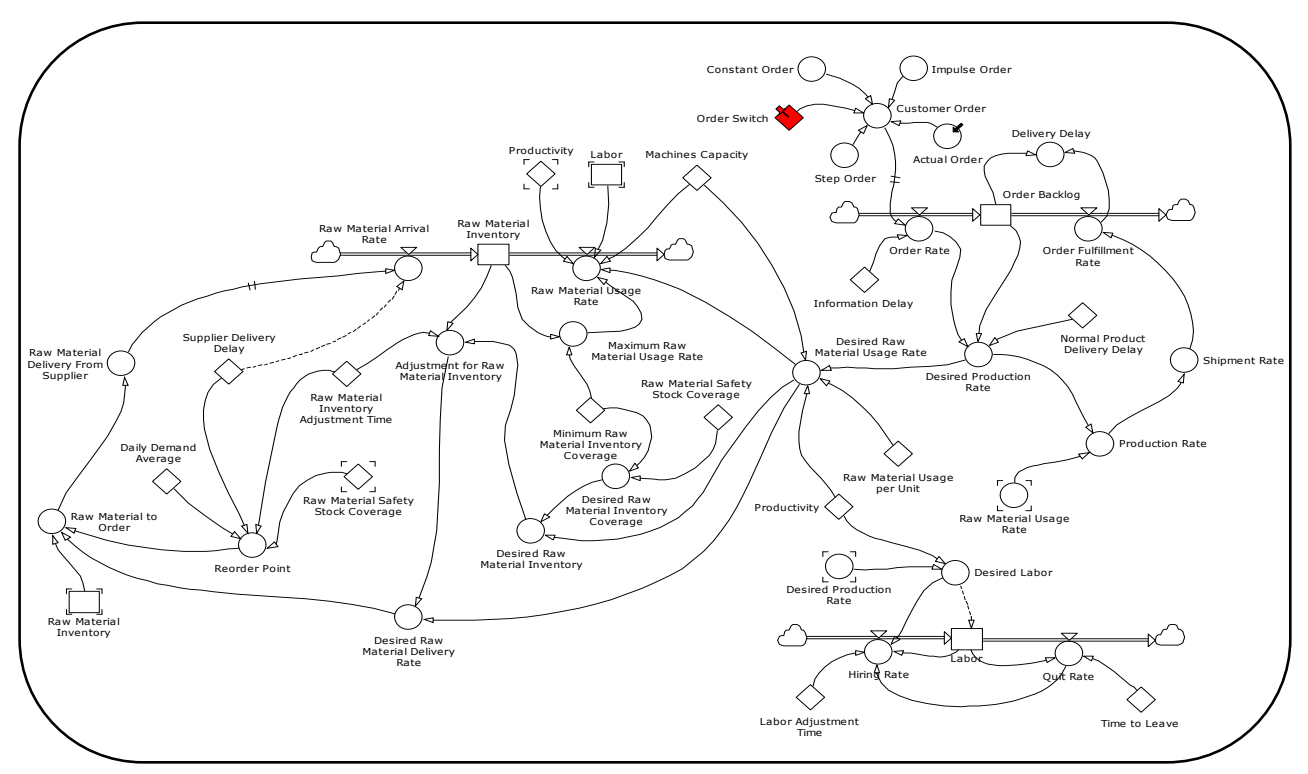

Gambar 4. Stock and Flow Diagram

Sebelum simulasi system dynamics dilakukan terlebih dahulu ditentukan batasan dan asumsi model yaitu :

a. Simulasi dinamik yang dilakukan adalah untuk menganalisis perilaku sistem menggunakan kurun waktu yang telah berlalu bukan untuk menganalisis perilaku sistem untuk masa mendatang.

b. Menganalisis pemenuhan pesanan untuk produk berupa tas standar berukuran 10 $\mathrm{cm} \times 30 \mathrm{~cm} \times 40 \mathrm{~cm}$. Selanjutnya untuk raw material usage per unit ditetapkan 1 unit produk membutuhkan 1 unit material berupa 0,25 meter kain, 10 meter benang, 0,25 meter parasut dan 1 set kelengkapan lain (resleuting, pengait tas, dan lain-lain).

c. Productivity diasumsikan konstan tidak terpengaruh oleh faktor beban kerja, kondisi pekerja, pengalaman dan lain sebagainya.

Hal lainnya adalah penentuan nilai konstanta. Penentuan nilai konstanta tertera dalam Tabel 2.

Tabel 2. Nilai konstanta

\begin{tabular}{ll}
\hline \multicolumn{1}{c}{ Nama } & \multicolumn{1}{c}{ Nilai } \\
\hline Labor adjustment time & 14 days \\
Information delay & 2 days \\
Minimum raw material inventory coverage & 1 days \\
Normal product delivery order & 1 days \\
Productivity & 6 units/ppl/day \\
Raw material inventory adjustment time & 7 days \\
Raw material safety stock coverage & 0 days \\
Raw material usage per unit & 1 unit \\
Supplier delivery delay & 2 days \\
Time to leave & 30 days \\
Machines capacity & 200 unit/day \\
\hline
\end{tabular}


Setelah dinyatakan lulus 3 tahapan kalibrasi maka dilakukan tahapan policy design dengan menggunakan 4 jenis skenario order yang berbeda. Adapun jenis order dijelaskan dalam Tabel 3.

Tabel 3. Jenis order

\begin{tabular}{|c|c|}
\hline Jenis Skenario & Keterangan \\
\hline Constant order & Skenario pesanan yang konstan sebesar 100 unit/hari. \\
\hline Impulse order & $\begin{array}{l}\text { Skenario pesanan seperti pada constant order tetapi terjad } \\
\text { penambahan pesanan sebesar } 100 \text { unit pada tanggal } 1 \text { bulan } \\
\text { Maret, April, Mei, Juni, Juli dan Agustus. }\end{array}$ \\
\hline Step order & $\begin{array}{l}\text { Skenario pesanan seperti pada constant order tetapi terjad } \\
\text { penambahan pesanan sebesar } 200 \text { unit pada tanggal } 1 \text { Juni } \\
2006 \text { dan bertahan pada level tersebut hingga berakhirnya } \\
\text { periode simulasi. Step order mengadopsi trend pesanan yang } \\
\text { dialami oleh perusahaan. Adapun besarnya adalah pada bulan } \\
\text { Februari sampai bulan Mei pesanan tas sebesar } 3.000 \\
\text { unit/bulan ( } 100 \text { unit/hari). Kemudian pada bulan Juni sampai } \\
\text { bulan Oktober mengalami peningkatan menjadi } 6.000 \\
\text { unit/bulan ( } 200 \text { unit/hari) karena pada bulan tersebut } \\
\text { bertepatan dengan dimulainya tahun ajaran baru bagi anak } \\
\text { anak sekolah dan banyaknya penyelenggaraan seminar. }\end{array}$ \\
\hline Actual order & $\begin{array}{l}\text { Skenario pesanan aktual yang diterima oleh perusahaan dalam } \\
\text { periode } 1 \text { Februari } 2006 \text { sampai } 1 \text { September } 2006 .\end{array}$ \\
\hline
\end{tabular}

Gambar 5 menunjukkan hasil simulasi menggunakan skenario constant order.
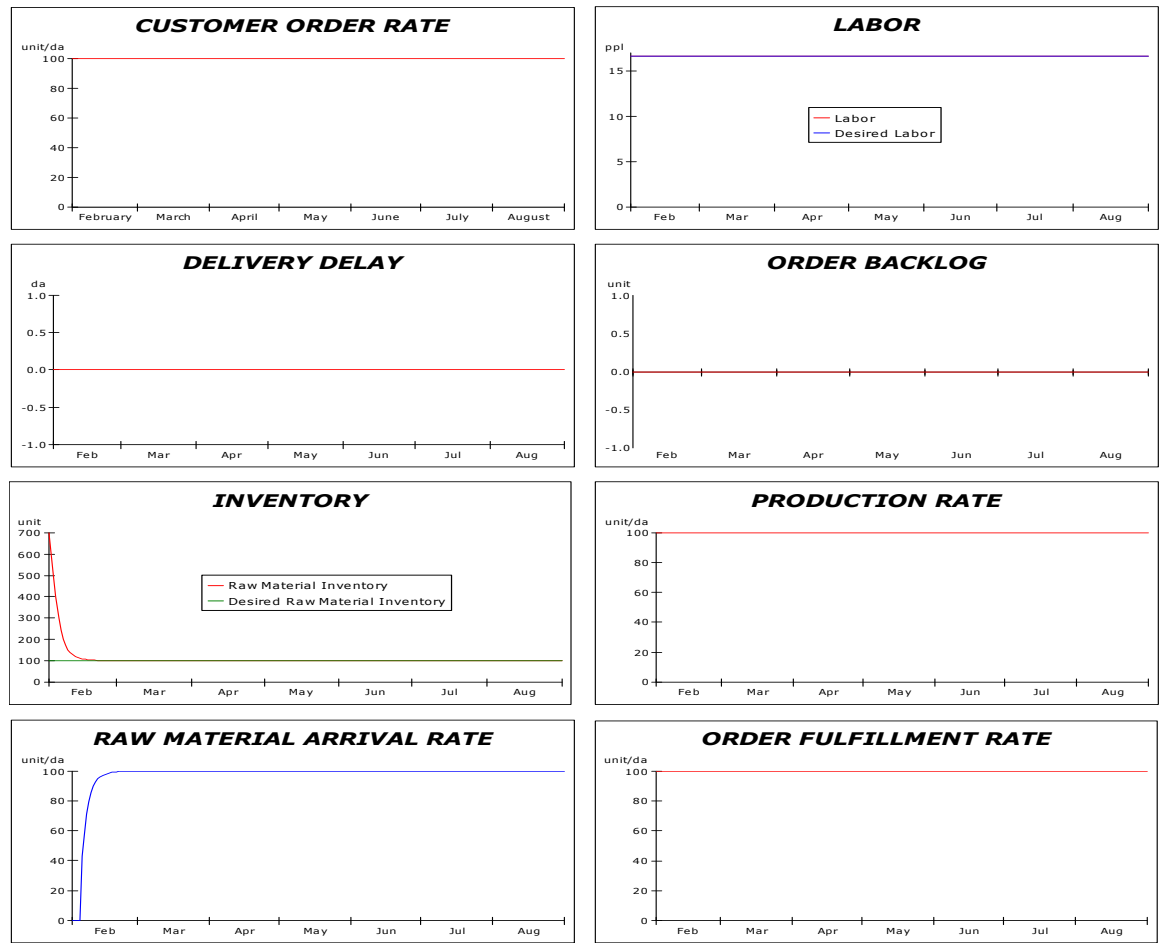

Gambar 5. Output Skenario Constant Order 
Berdasarkan Gambar 5 di atas, sistem menunjukkan perilaku yang baik karena tidak terdapat order backlog dan delivery delay. Sejak awal simulasi hingga periode simulasi berakhir, production rate dan order fulfillment rate konstan pada level 100 unit/hari sehingga mampu memenuhi seluruh order yang diterima. Tingkat produksi ditunjang pula oleh keadaan raw material inventory.

Pada awal simulasi raw material inventory sebesar 700 unit. Selanjutnya perlahanlahan turun hingga pada tanggal 9 Maret 2006 mencapai 100 unit dan tetap konstan pada level ini hingga periode simulasi berakhir. Perilaku raw material inventory dipengaruhi oleh raw material arrival rate. Keadaan pemesanan raw material yang terus-menerus dipengaruhi pula oleh tingkat kebutuhan jenis dan tipe raw material yang tentunya memiliki perbedaan sesuai dengan spesifikasi pesanan yang diterima.

Sedangkan untuk kebutuhan tenaga kerja (labor) menunjukkan perilaku yang konstan sebesar $16,67 \approx 17$ orang yang berlangsung dari awal hingga periode simulasi berakhir. Hal ini terjadi karena kebutuhan tenaga kerja secara langsung dipengaruhi oleh customer order rate yang konstan sebesar 100 unit/hari.

Gambar 6 menunjukkan hasil simulasi menggunakan skenario impulse order.
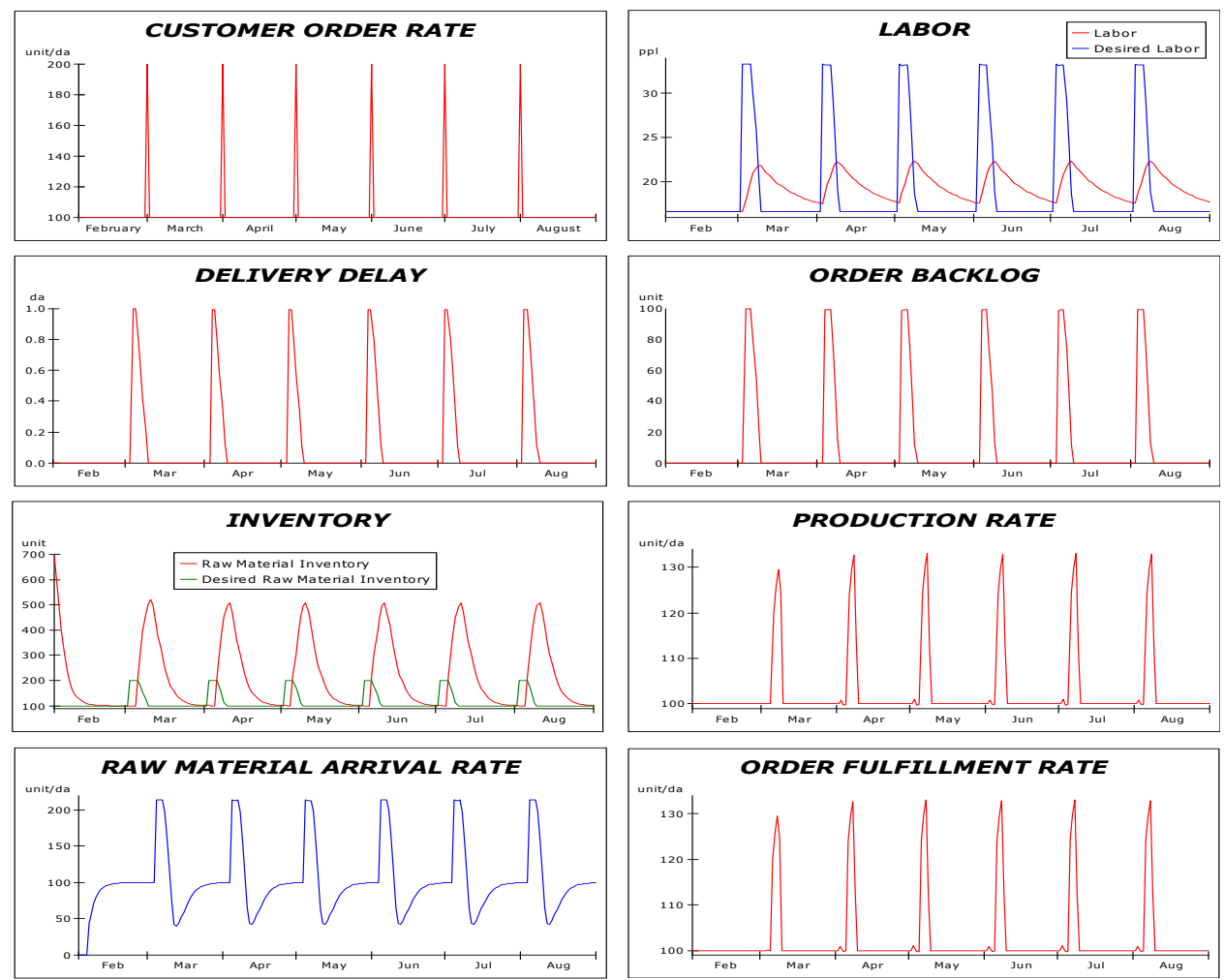

Gambar 6. Output Skenario Impulse Order

Berdasarkan Gambar 6 di atas, sistem menunjukkan perilaku sebagai berikut :

Muncul order backlog dan delivery delay dimulai sejak terjadi peningkatan order semenjak tanggal 1 Maret 2006. dalam interval waktu 1 bulan perilaku ini terulang kembali mengikuti pola impulse order yang diterima oleh perusahaan.

Perilaku production rate dan order fulfillment rate menunjukkan pola yang sama yaitu konstan pada level 100 unit/hari dengan terjadi fluktuasi terutama pada setiap 
awal bulan di mana terjadi fluktuasi order yang diterima. Production rate dan order fulfillment rate meningkat pada awal-awal bulan pada tanggal 3 setiap bulannya kecuali pada bulan Februari. Hal ini karena terdapat faktor information delay sebesar 2 hari yang diterima oleh pihak perusahaan.

Perilaku labor dan inventory menunjukkan perilaku yang sama seperti yang dialami oleh production rate dan order fulfillment rate. Perilaku labor dipengaruhi oleh hiring rate dan quit rate. Sedangkan perilaku inventory dipengaruhi oleh perilaku arrival raw material rate yang menunjukkan fluktuasi karena pemesanan raw material hanya dilakukan jika keadaan raw material inventory kurang atau telah mencapai reorder point. Kedatangan raw material juga dipengaruhi dengan adanya supplier delivery delay sebesar 2 hari.

Peningkatan order pada awal bulan Juni 2006 mengakibatkan terjadinya order backlog dan delivery delay setelah sebelumnya bernilai nol. Hal ini disebabkan karena terbatasnya production rate dan order fulfillment rate yang langsung dipengaruhi oleh machines capacity sebesar 200 unit/hari.

Perilaku labor, inventory dan raw material arrival rate menunjukkan peningkatan pada periode terjadinya peningkatan order. Sedangkan perilaku raw material inventory dipengaruhi langsung oleh raw material arrival rate yang berfluktuasi yang diformulasikan mengikuti pemesanan raw material yang dilakukan telah mencapai reorder point. Secara keseluruhan perilaku sistem berdasarkan skenario step order ditunjukkan pada Gambar 7.
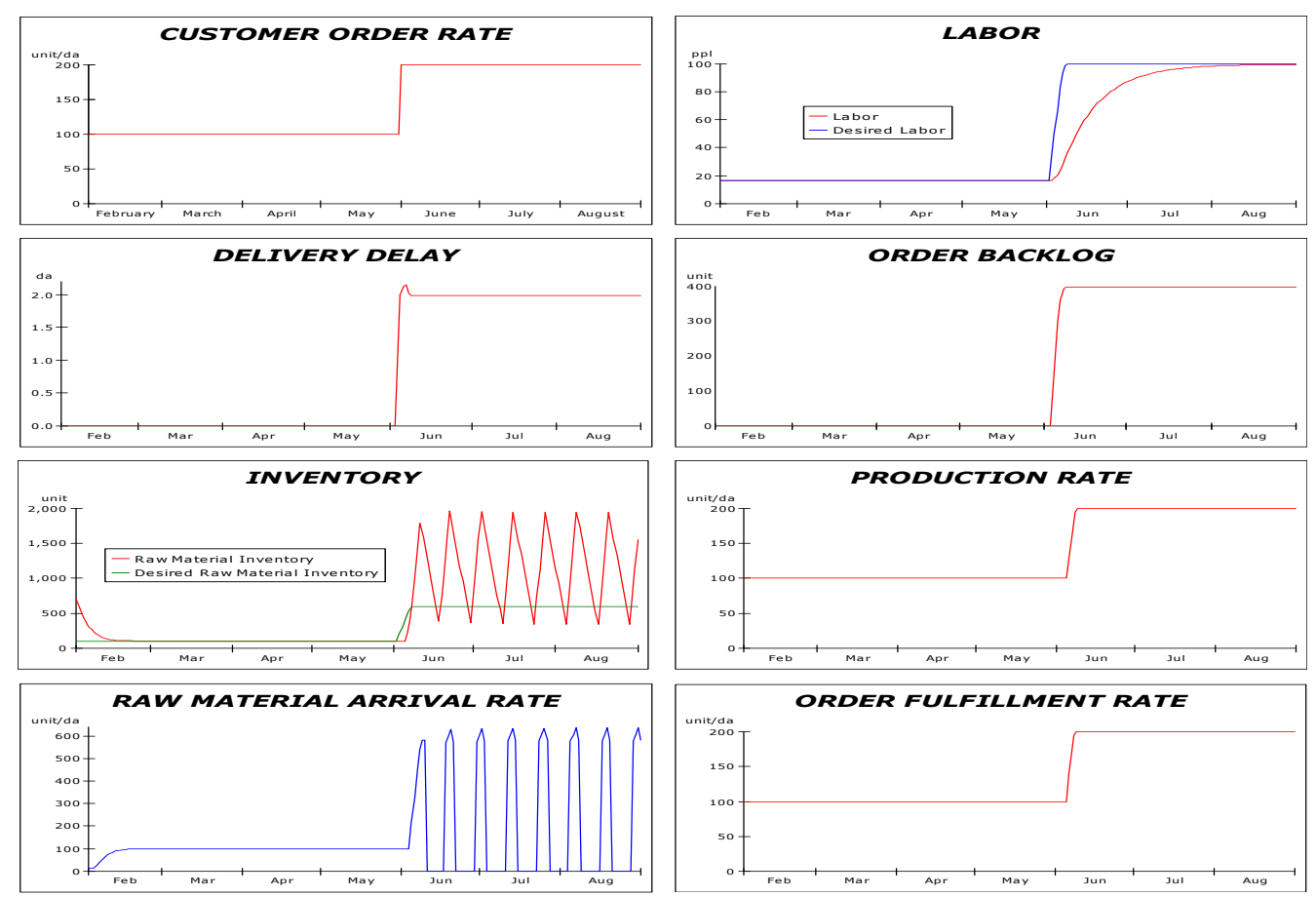

Gambar 7. Output Skenario Step Order 
Gambar 8 menunjukkan hasil simulasi menggunakan skenario actual order.
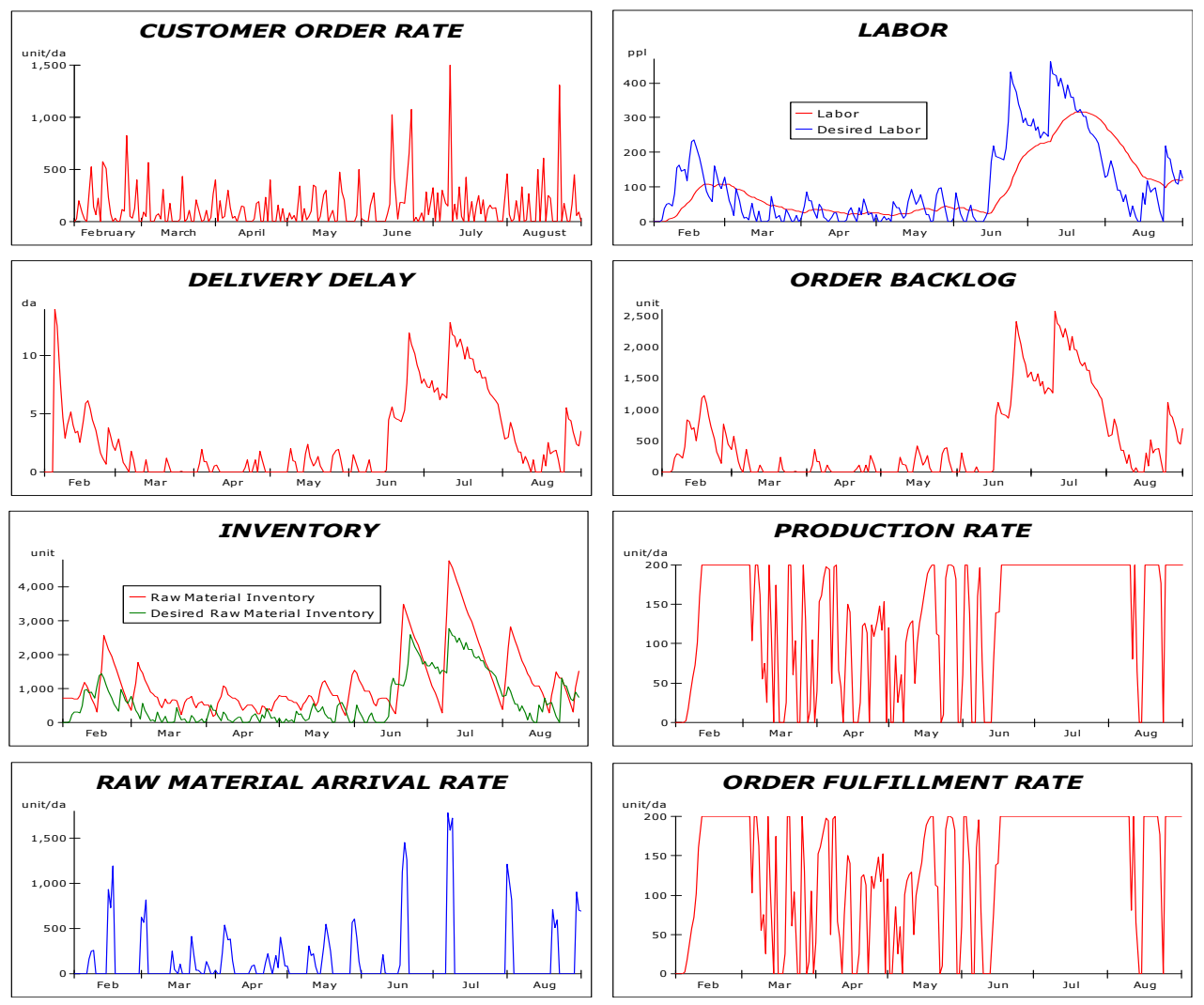

Gambar 8. Output Skenario Actual Order

Berdasarkan Gambar 8 di atas, sistem menunjukkan perilaku yang berfluktuasi. Hal ini karena dipengaruhi oleh customer order rate yang berfluktuasi pula.

Setelah dilakukan evaluasi terhadap keempat jenis skenario yang telah dilakukan maka selanjutnya diusulkan beberapa alternatif yang dapat diterapkan dalam rangka perbaikan sistem pemenuhan pesanan pelanggan. Berdasarkan skenario actual order, maka perbaikan sistem berfokus kepada peningkatan production rate yang akhirnya berakibat kepada pereduksian jumlah order backlog dan delivery delay. Skenario actual order dipilih sebagai skenario penerapan alternatif perbaikan karena jenis skenario ini merepresentasikan keadaan customer order secara nyata sehingga diharapkan jika skenario actual order mampu merespon alternatif perbaikan dengan baik maka dimungkinkan jenis-jenis skenario lainnya mengalami perbaikan.

Adapun alternatif perbaikan yang diusulkan adalah : penambahan machines capacity, kombinasi antara penambahan machines capacity dan productivity serta penurunan information delay. Alternatif perbaikan yang terakhir adalah kombinasi antara penambahan machines capacity serta pengurangan information delay dan labor adjustment time.

Perbandingan hasil sebelum perbaikan sistem dengan hasil setiap alternatif perbaikan sistem berdasarkan skenario constant order tersaji dalam Tabel 4. 
Tabel 4. Perbandingan Hasil Sebelum dan Setelah Perbaikan Sistem Selama Periode Simulasi

\begin{tabular}{|c|c|c|c|c|}
\hline \multirow[b]{2}{*}{ Variabel } & \multicolumn{4}{|c|}{ Akumu;asi Nilai dalam 7 bulan) } \\
\hline & $\begin{array}{c}\text { Kondisi } \\
\text { Awal }\end{array}$ & $\begin{array}{c}\text { Alternatif } \\
1 \\
\end{array}$ & $\begin{array}{c}\text { Alternatif } \\
2 \\
\end{array}$ & $\begin{array}{c}\text { Alternatif } \\
3 \\
\end{array}$ \\
\hline \multirow{2}{*}{$\begin{array}{l}\text { Production rate } \\
\text { [unit/day] }\end{array}$} & \multirow{2}{*}{29257} & 29637,33 & \multirow{2}{*}{29802} & 29784,19 \\
\hline & & $\approx 29637$ & & $\approx 29784$ \\
\hline \multirow{2}{*}{ Delivery delay [day] } & 577,71 & 221,34 & 240,35 & 185,31 \\
\hline & $\approx 578$ & $\approx 221$ & $\approx 240$ & $\approx 185$ \\
\hline \multirow{2}{*}{ Order backlog [unit] } & 105849,42 & 41027,52 & 40720,22 & 40144,14 \\
\hline & $\approx 105849$ & $\approx 41028$ & $\approx 40720$ & $\approx 40144$ \\
\hline \multirow{2}{*}{ Labor [people] } & 20921,22 & 10832,55 & 6458,06 & 11132,55 \\
\hline & $\approx 20921$ & $\approx 10833$ & $\approx 6458$ & $\approx 11133$ \\
\hline
\end{tabular}

Keterangan :

Alternatif 1 : penambahan machines capacity.

Alternatif 2 : kombinasi antara penambahan machines capacity dan productivity serta pengurangan information delay.

Alternatif 3 : kombinasi antara penambahan machines capacity dengan pengurangan information delay dan labor adjustment time.

Berdasarkan Tabel 4 alternatif perbaikan ketiga menghasilkan perbaikan yang lebih baik (dengan indikator utama nilai order backlog dan delivery delay terkecil). Akan tetapi terdapat fenomena menarik yaitu jika dibandingkan dengan production rate hasil alternatif perbaikan kedua ternyata production rate hasil alternatif perbaikan ketiga lebih kecil. Hal ini terjadi karena production rate hasil alternatif ketiga pada awal simulasi lebih besar daripada production rate hasil alternatif kedua sehingga menghasilkan order backlog dan delivery delay yang rendah meskipun secara akumulasi lebih kecil hasilnya daripada akumulasi production rate hasil alternatif ketiga.

Selain itu dengan merujuk Tabel 4, perusahaan dihadapkan terhadap adanya mempertimbangkan trade off dari setiap alternatif perbaikan sistem seperti faktor biaya dan sebagainya. Akan tetapi pada kesempatan ini tidak diputuskan alternatif perbaikan apa yang harus diambil karena penelitian ini lebih berfokus menjelaskan fenomena sistem dinamik. Serta antara peneliti dengan pihak klien belum mampu menjabarkan, merumuskan serta menetapkan besarnya elemen-elemen biaya yang muncul untuk melakukan setiap alternatif perbaikan tersebut.

\section{Kesimpulan}

Faktor-faktor yang mempengaruhi kebijakan dalam manajemen pemenuhan pesanan pelanggan CV. Kurnia Jaya tercakup dalam key variables yaitu order backlog, delivery delay, production rate, raw material inventory dan labor. Model simulasi system dynamics yang dikembangkan telah berhasil dibuat dan telah lulus kalibrasi berupa model boundary diagram test, extreme condition test dan behaviour anomaly test. Model sistem pemenuhan pesanan pelanggan terbagi menjadi 4 sub model yaitu sub model customer order, sub model order fulfillment, sub model raw material management dan sub model labor. Dinamika manajemen pemenuhan pesanan pelanggan CV. Kurnia Jaya berdasarkan policy design menggunakan 4 skenario yaitu constant order, step order, impulse order dan actual order memperlihatkan perilaku 
Perubahan customer order baru dapat direspon menjadi order rate yang diterima pada 2 hari kemudian. Hal ini karena terdapatnya faktor information delay sebesar 2 hari. Sistem pemenuhan pesanan pelanggan mampu merespon customer order yang terjadi jika customer order yang terjadi relatif konstan. Akan tetapi jika customer order terjadi peningkatan secara step (bertingkat) mencapai nilai maksimum machines capacity dan customer order yang berfluktuasi maka sistem belum merespon hal tersebut dengan baik dengan indikator masih terjadinya peningkatan order backlog dan delivery delay dibandingkan dengan jenis customer order yang relatif konstan. Alternatif perbaikan sistem yang dapat dilakukan pada sistem (diwakili menggunakan skenario actual order) adalah penambahan machines capacity, kombinasi antara penambahan machines capacity dan productivity serta penurunan information delay, atau kombinasi antara penambahan machines capacity serta pengurangan information delay dan labor adjustment time.

\section{Daftar Pustaka}

Brownell, J., December 2004, Managing Merchandise 'Flow' Straight to The Corporate Top Line, article at www.supplychainbrain.com, online August $11^{\text {th }}, 2006$.

Forrester, J.W., July $13^{\text {th }}, 1989$, The Beginning of System Dynamics, Banquet Talk at The International Meeting of The System Dynamics Society, Stuttgart, Germany.

Haroon, M. I., and Wahba, K., 2002, A Generic Tool Based on Systems Dynamics Approach to Assess SME Business Stability and Help Designing Business Tactics and Action Plans Within Transient, Non - Stationary Conditions.

Mulyani, S., 2006, Management of Change, Generic Competencies Training Module of Mechanics for Automotive Retooling Program BATCH IV, $2^{\text {nd }}$ module, UGM, Yogyakarta.

Murphy, J. V., 2004, Advanced Order Fulfillment Requires Warehouses With 'On Demand' Capability, article at www.supplychainbrain.com, online August $11^{\text {th }}$, 2006.

Rohmah, F. A., 2006, Kemampuan Mengenali Potensi Diri, Generic Competencies Training Module of Mechanics for Automotive Retooling Program BATCH IV, $1^{\text {st }}$ modul, UGM, Yogyakarta.

Samhadi, S. H., Sabtu 15 April 2006, Sektor Informal, Fokus Harian Umum Kompas.

Sopha, B. M., dan Hartono, B., Februari 2006, Pengembangan Framework Dinamika Rantai Pasok untuk Pengembangan Pemasok pada Industri Kecil dan Menengah, Usulan Penelitian yang Diajukan Kepada Fakultas Teknik Universitas Gadjah Mada, Yogyakarta.

Sterman, J. D., 2000, Business Dynamics : System Thinking and Modeling for a Complex World, The McGraw - Hill Companies, Inc, USA. 